\section{Recycling of waste plastics to liquid fuel mixture over composite zeolites catalysts}

F. Akhmetova ${ }^{1 *}$, Y. Aubakirov ${ }^{1}$ Zh. Tashmukhambetova ${ }^{1}$, L. Sassykova ${ }^{1}$ H. Arbag', A. Kurmangaliyeva

${ }^{1}$ Al-Farabi Kazakh National University, Almaty, Kazakhstan ${ }^{2}$ Gazi University, Ankara, Turkey E-mail: firuza.92@mail.ru
Plastic waste production and consumption is increasing at an alarming rate with the increase of the human population, rapid economic growth, continuous urbanization, and changes in lifestyle. In addition, the short life span of plastic accelerates the production of plastic waste on a daily basis. Plastic waste recycling is carried out in different ways, but in most developing countries, open or landfill disposal is a common practice for plastic waste management. Plastic recycling into feedstocks, also known as chemical recycling, is encouraged all over the world. One such area is the thermal and catalytic thermal degradation of plastics into hydrocarbon fractions, which can be used as high-quality motor fuel after appropriate processing. Hydrocracking in the presence of a catalyst is a promising method of converting waste plastic materials to high quality liquid transportation fuels with decreased amounts of olefins and heteroatoms such as $\mathrm{S}, \mathrm{N}, \mathrm{Cl}$, $\mathrm{N}$, and $\mathrm{O}$.

The article deals with the study of hydrocracking of waste plastic into high quality liquid fuel on various catalysts based on natural zeolite deposits Taizhuzgen. The aim of the work is to determine the effect of new composite catalysts on the yield of liquid products by studying the specific surface and porous structure based on natural zeolite modified with Mo salt. It is established that the modification of natural zeolite with Mo affects the morphology of the catalyst, therefore, the obtained catalysts have different effects on the yield and composition of liquid fractions during the hydrogenation thermocatalytic transformation of hydrocarbons. The highest yield of liquid products (61.56\%) was achieved using the $2 \%$ Mo/Taizhuzgen zeolite catalyst, which was chosen as optimal.

Keywords: polymer wastes; hydrogenation thermocatalytic recycling; zeolite; morphology of catalysts; hydrocracking.

\section{Пластмасса қалдықтарын сұйық отынға композитті цеолитті катализаторлар қатысында өндеу}

Ф. Ахметова ${ }^{1 *}$, Е. Аубакиров ${ }^{1}$ Ж. Ташмухамбетова ${ }^{1}$, Л. Сасыкова ${ }^{1}$ Х. Арбаг ${ }^{2}$ А. Курмангалиева

1Әл-Фараби атындағы Қазақ ұлттық университеті, Алматы, Қазақстан ГГази университеті, Анкара, Түркия *E-mail: firuza.92@mail.ru
Пластикалық қалдықтарды өндіру және тұтыну халық санының ұлғаюымен, экономиканың қарқынды өсуімен, үздіксіз урбанизациялаумен және өмір салтындағы өзгерістермен артуда. Сонымен қатар, пластик заттарды қолдану пластикалық қалдықтардың артүына әкеледі. Пластикалық қалдықтарды қайта өңдеу әр түрлі тәсілдермен жүзеге асырылады, бірақ дамушы елдердің көпшілігінде ашық немесе үйінділі кәдеге жарату пластикалық қалдықтармен жұмыс істеудің әдеттегі тәжірибесі болып табылады. Пластикті шикізатқа қайта өңдеу, сонымен қатар одан пайдаль мотор отындарын алу негізгі мәселелердің бірі болып табылады. Мұндай салалардың бірі - пластмассаның көмірсутегі фракцияларына термиялық және каталитикалық термодеструкциясы және өңдеуден кейін жоғары сапалы мотор отыны ретінде пайдаланылуы. Гидрокрекинг процесі Тайжүзген табиғи цеолиті негізіндегі катализатордың қатысуымен пластмасса қалдықтарын S, N, Cl, N және О сияқты төмен олефиндер мен гетеротомдары бар жоғары сапалы сұйық көлік отындарына айналдырудың перспективалық әдісі болып табылады.

Мақала Тайжүзген табиғи цеолит кен орындары негізіндегі түрлі катализаторлар қатысында пластмассалардың гидрокрекингін зерттеуге және жоғары сапалы сұйық отын алуға негізделген. Жұмыстың мақсаты Мо тұзымен модификацияланған табиғи цеолит негізіндегі жаңа композитті катализаторлардың меншікті беті мен кеуекті құрылымын зерттеу арқылы сұйық өнімдердің шығымына әсерін анықтау болып табылады. Табиғи цеолитті Мо тұзымен модификациялау катализатордың морфологиясына әсер ететін анықталды, сондықтан алынған катализаторлар көмірсутектердің гидрогенизациялық термокаталитикалық өңдеуде сұйық фракциялардың шығымы мен құрамына әр түрлі әсер етеді.

Түйін сөздер: полимер қалдықтары; гидрогенизациялық термокатализдік өңдеу; цеолит; катализатор морфологиясы; гидрокрекинг.

\section{Переработка отходов пластмасс в жидкое топливо на цеолитных катализаторах}

Ф. Ахметова ${ }^{1 *}$, Е. Аубакиров ${ }^{1}$ ж. Ташмухамбетова ${ }^{1}$, Л. Сасыкова ${ }^{1}$ Х. Арбаг ${ }^{2}$ А. Курмангалиева

${ }^{1}$ Казахский национальный университет имени аль-Фараби, Алматы, Казахстан

университет Гази, Анкара, Түрция *E-mail: firuza.92@mail.ru
Производство и потребление пластиковых отходов растет тревожными темпами с увеличением численности населения, быстрым экономическим ростом, непрерывной урбанизацией и изменениями в образе жизни. Переработка пластика в сырье, также известное как химическая переработка, поощряется во всем мире. Одной из таких областей является Термическая и каталитическая термодеструкция пластмасс на углеводородные фракции могут быть использованы в качестве высококачественного моторного топлива после соответствующей переработки. Гидрокрекинг в присутствии катализатора является перспективным методом превращения отходов пластмасс в высококачественные жидкие транспортные топлива с пониженным содержанием олефинов и гетероатомов, таких как S, N, Cl, N и O.

Статья посвящена исследованию гидрокрекинга отработанных пластмасс в высококачественное жидкое топливо на различных катализаторах на основе природных цеолитов месторождений Тайжузген. Целью работы является определение влияния новых композитных катализаторов на выход жидких продуктов путем исследования удельной поверхности и пористой структуры на основе природного цеолита, модифицированного солью Мо. Установлено, что модификация природного цеолита солью Мо оказывает влияние на морфологию катализатора, поэтому полученные катализаторы по-разному влияют на выход и состав жидких фракций при гидрогенизационном термокаталитическом превращении углеводородов.

Ключевые слова: полимерные отходы; гидрогенизационная термокаталитическая переработка; цеолит; морфология катализаторов; гидрокрекинг. 


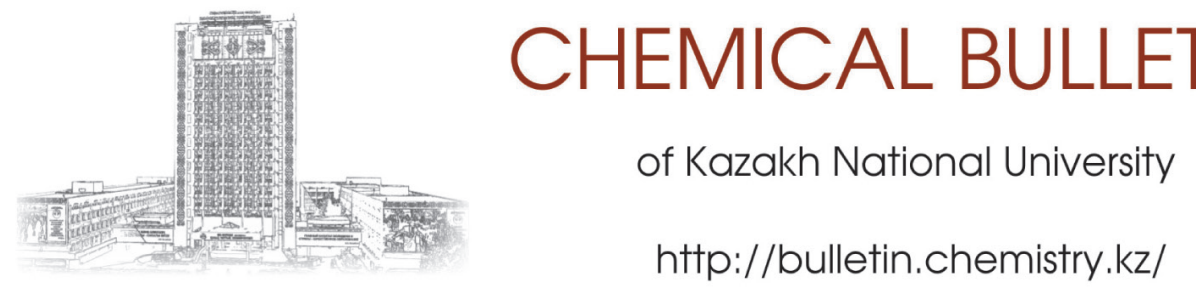

\title{
Recycling of waste plastics to liquid fuel mixture over composite zeolites catalysts
}

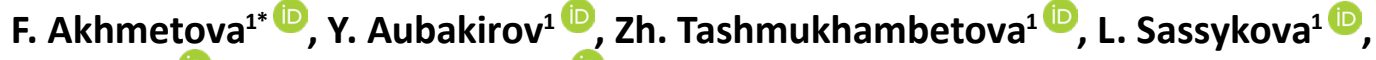 \\ H. Arbag ${ }^{2}$, A. Kurmangaliyeva1 ${ }^{1}$
}

${ }^{1}$ Al-Farabi Kazakh National University, 71 al-Farabi Ave., Almaty 050040, Kazakhstan

${ }^{2}$ Gazi University, Gazi Üniversitesi Rektörlügü, Teknikokullar Ankara, Ankara 06500, Turkey

*E-mail: firuza.92@mail.ru

\section{Introduction}

Plastics play an important role in our daily life, and our ever-growing dependence on them is justified by their versatility, low weight and low cost of production compared to other classic materials such as wood, concrete and metal [1]. The production of plastic materials such as polyethylene (PE), polypropylene (PP), polystyrene (PS), polyethylene terephthalate (PET) and polyvinyl chloride (PVC) is increasing every year [2] due to their consumption in packaging, construction, agriculture, electrical and electronic devices and healthcare applications [3].

The current state of raw material processing, also known as chemical processing or tertiary processing, is aimed at converting polymer waste into original monomers or other valuable chemicals. These products are useful as raw materials for a variety of downstream industrial processes or as transportation fuel. There are three main approaches: depolymerization, partial oxidation, and cracking (thermal, catalytic, and hydrocracking) [4]. Thermal degradation of plastics is of great concern in connection with the processing of raw materials, as they are converted into gas, liquid (oil) and solid products, each of which can be used as a source of energy and/or chemical raw materials. Plastic waste can be a valuable alternative source of energy production $[5,6]$. The composition and yield of pyrolysis products directly depend on the reaction conditions (temperature, heating rate, pressure, presence of a catalyst, etc.), as well as on the structure of the aspirated material [7-10]. The interaction between materials in food waste has a significant impact on the selection of individual components of the liquid product [11-13].

Catalysts play an important role in hydrocracking of plastics. A bifunctional catalyst is usually needed for this purpose. The presence of an acidic function, as well as a hydrogenation-dehydrogenation function, is usually necessary to achieve significant conversion, high yield and high quality of liquid products, and to reduce the amount of coke deposits [3]. It is well known that porous materials such as zeolites, carbon, meso-porous materials, and other molecular sieve materials are one of the most popular catalytic materials that are widely used in the oil refining and chemical industries. Due to the rapid reduction of workings and the high demand for environmental protection, it is urgent to develop new high-performance catalysts, especially with porous materials [14]. At a lower temperature $\left(400^{\circ} \mathrm{C}\right)$ virtually similar results were obtained with both catalysts, while at a higher temperature, $430^{\circ} \mathrm{C}$, the Mo-containing zeolite catalyst was more active in converting polyethylene to reaction products $[15,16]$. New catalysts based on the natural zeolite of the Taizhuzgen Deposit modified by Mo (VI) salt will be actively and selectively used for the process under study [17].

The aim of the work is to study the effect of new composite catalysts on the yield of liquid products by studying the specific surface area and porous structure based on natural zeolite modified modified by Mo (VI) salt [18].

\section{Experiment}

\subsection{Preparation of catalysts}

Zeolite at the "Taizhuzgen" field was crushed with a sieve up to $0.25 \mathrm{~mm}$ in size. Zeolite $(10 \mathrm{~g})$ was mixed with $500 \mathrm{~mL}$ of $1 \mathrm{M} \mathrm{NH}_{4} \mathrm{Cl}$ solutionon a water bath using a mechanical stirrer for $18 \mathrm{~h}$ (three times for $6 \mathrm{~h}$ ). After washing the Taizhuzgen zeolite with $\mathrm{NH}_{4} \mathrm{Cl}, \mathrm{NH}_{4}^{+}$and $\mathrm{Cl}^{-}$ions remain inside the zeolite. Zeolite was filtered from $\mathrm{NH}_{4} \mathrm{Cl}$ solution and washed with distilled water till the compete removal of $\mathrm{Cl}$-ions. Absence of chlorine 
ions was confirmedusing a reaction with a $0.1 \mathrm{~mol} / \mathrm{LAgNO}_{3}$. Filtered zeolite was dried till the constant mass in a drying oven SNOL 75/350 (AB UMEGA, Lithuania) at $100^{\circ} \mathrm{C}$.To remove ammonia gas and keep $\mathrm{H}^{+}$ions, zeolite was heated in the reactor at $100^{\circ} \mathrm{C}(1 \mathrm{~h}), 200^{\circ} \mathrm{C}(1 \mathrm{~h}), 300^{\circ} \mathrm{C}(1 \mathrm{~h})$ and $500^{\circ} \mathrm{C}(1 \mathrm{~h})$.

To prepare four catalysts with a different Mo concentration $(0.5,1.0,1.5$ and $2.0 \% \mathrm{w} / \mathrm{w})$, different volumes of a solution of $\left(\mathrm{NH}_{4}\right)_{6} \mathrm{Mo}_{7} \mathrm{O}_{24} \cdot 4 \mathrm{H}_{2} \mathrm{O}$ were added to zeolite, which was then dried at $100^{\circ} \mathrm{C}$ till the constant mass and stored in a desiccator with $\mathrm{CaCl}_{2}$.

\subsection{Hydrogenation}

The hydrogenation was carried out in the installation (Figure 1) operating in a periodic mode under a pressure of $0.5 \mathrm{MPa}$, at a temperature of up to $450^{\circ} \mathrm{C}$ andcontinuous stirring for $15 \mathrm{~min}$. The installation consisted of a stainless steel (X18N10T) reactor with a volume of $150 \mathrm{~mL}$. The reactor was heated using an alternating current heater controlled by a transformer and an ammeter. The temperature control in the reactor was carried out using a chromel-drop thermocouple. The readings were recorded on the KSP-4 device with a calibrated scale for the boiling points of water $\left(100^{\circ} \mathrm{C}\right)$, melting of tin $\left(232^{\circ} \mathrm{C}\right)$, lead $\left(327^{\circ} \mathrm{C}\right)$ and $\operatorname{zinc}\left(427^{\circ} \mathrm{C}\right)$. Thepressure in the hydrogenation unit was created using nitrogen and measured using a gauge. A mixture of the polymer $(7 \mathrm{~g})$, a catalyst $(0.28 \mathrm{~g})$ and the paste-forming agent $(7 \mathrm{~g})$ was loaded into the reactor, then the reactor was checked for tightness, purged with nitrogen, a pressure of 0.5-0.6 MPa was set, after which the heating device was turned on. Caps for the plastic bottles produced by Bericap Kazakhstan LLP, collected from drinks produced by the Coca-Cola Almaty Bottlers LLP) and crushed to the particle size of 3-6 mm were used as a polymer material. Heavy residue of the crude oil from Kumkol petroleum reservoir after its distillation to $350^{\circ} \mathrm{C}$ was used the paste-forming agent.
Using a pressure gauge during hydrogenation, a pressure change was recorded due to an increase in temperature, gas separation and the presence of volatile components. The reactor heating was turned off $30-40$ min after starting the process (when the pressure decreased), and the system was cooled to room temperature. The gas formed in the process was collected in a gasometer with a saturated $\mathrm{NaCl}$ solution. The amount of gas formed was calculated from the pressure difference.

The distillation of the liquid product with separation to different temperature $\left(0-180^{\circ} \mathrm{C}, 180-250^{\circ} \mathrm{C}, 250-320^{\circ} \mathrm{C}\right)$ fractions was carried out at the installation (Figure 1). For this purpose, a condenser with a receiver was connected to the nozzle of the reactor cooled to room temperature. During the distillation, the reactor was heated, and different temperature fractions were collected. After cooling the unit, the remaining residue was removed from the reactor.

Each experiment was conducted three times under the same conditions. The deviation between the results of the experiments did not exceed $2 \%$.

\subsection{Characterization}

Samples of activated zeolite and $\mathrm{Mo}(\mathrm{VI}) /$ zeolite catalysts were analyzed on the JSM-6460LV (JEOL, Japan) scanning electron microscope.

Analysis of liquid distillates using gas chromatography with mass spectrometric detection (GC-MS) was performed on the $6890 \mathrm{~N} / 5973 \mathrm{~N}$ (Agilent, USA) instrument. Liquid sample $(0.2$ $\mu \mathrm{L}$ ) was introduced at $500: 1$ split and $240^{\circ} \mathrm{C}$ to the HP-INNOWax (Agilent, USA) $30 \mathrm{~m} \times 0.25 \mathrm{~mm}$ column (film thickness $0.25 \mu \mathrm{m}$ ). Oven temperature was programmed from $50^{\circ} \mathrm{C}$ (maintained for $5 \mathrm{~min}$ ) to $240^{\circ} \mathrm{C}$ (maintained for $10 \mathrm{~min}$ ). Total analysis time was $34 \mathrm{~min}$. Detector scanned ions in $\mathrm{m} / \mathrm{z}$ range 10-350 amu. Identification of peaks was conducted using NIST'08 mass spectral library.

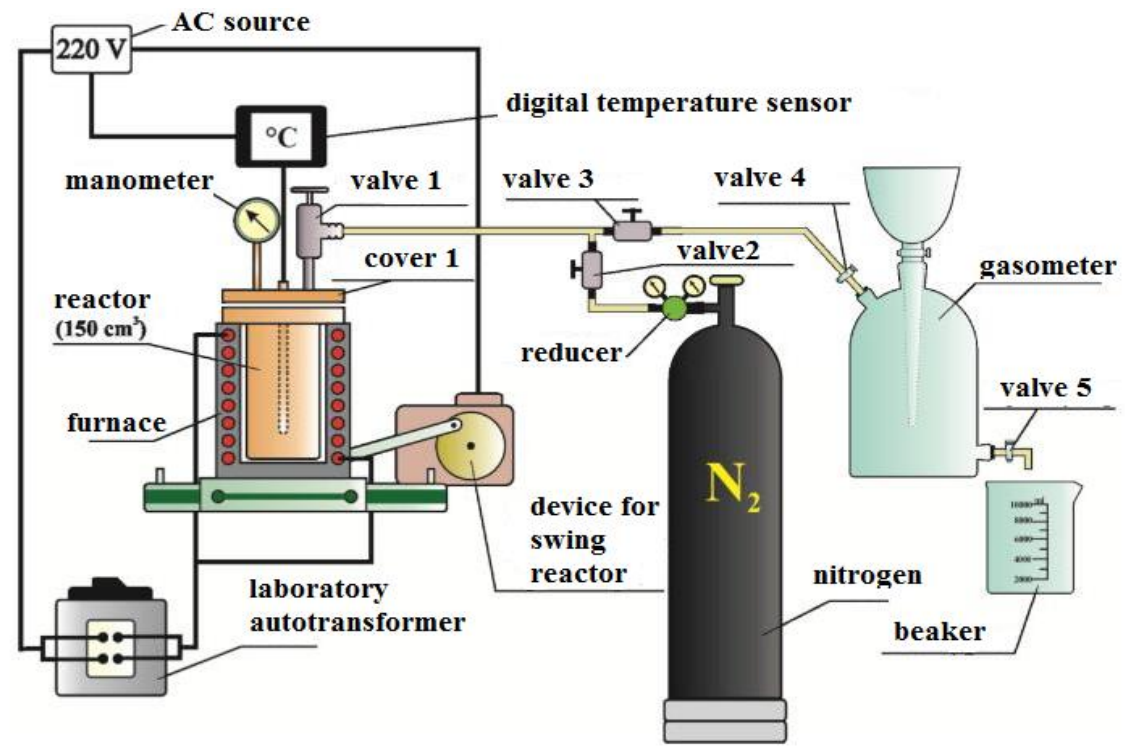

Figure 1 - Scheme of the installation used for catalytic hydrogenation of polymer waster [19] 
Table 1 - Chemical composition of Taizhuzgen zeolite, \%

\begin{tabular}{llllllllllll}
\hline $\mathrm{SiO}_{2}$ & $\mathrm{TiO}_{2}$ & $\mathrm{Al}_{2} \mathrm{O}_{3}$ & $\mathrm{Fe}_{2} \mathrm{O}_{3}$ & $\mathrm{FeO}$ & $\mathrm{MnO}_{2}$ & $\mathrm{MgO}$ & $\mathrm{CaO}$ & $\mathrm{Na}_{2} \mathrm{O}$ & $\mathrm{K}_{2} \mathrm{O}$ & $\mathrm{SO}_{2}$ & $\mathrm{H}_{2} \mathrm{O}$ \\
\hline 65.15 & 0.23 & 14.25 & 0.90 & 0.54 & 0.10 & 0.74 & 3.16 & 2.17 & 2.74 & 0.05 & 9.97 \\
\hline
\end{tabular}

Table 2 - Elemental composition of Taizhuzgen zeolite

\begin{tabular}{lllllllllll}
\hline Element & $\mathrm{O}$ & $\mathrm{Si}$ & $\mathrm{Al}$ & $\mathrm{K}$ & $\mathrm{Ca}$ & $\mathrm{Fe}$ & $\mathrm{Na}$ & $\mathrm{Mg}$ & $\mathrm{Ti}$ & $\mathrm{Mn}$ \\
\hline Concentration, mass.\% & 49.26 & 34.62 & 7.62 & 3.11 & 1.78 & 1.49 & 1.30 & 0.51 & 0.19 & 0.12 \\
\hline
\end{tabular}

\section{Results and Discussion}

The main chemical compounds of natural zeolites are $\mathrm{SiO}_{2}$ and $\mathrm{Al}_{2} \mathrm{O}_{3}$. Y-type zeolites have $\mathrm{SiO}_{2} / \mathrm{Al}_{2} \mathrm{O}_{3}$ ratio about 2-3, X-type zeolite -3-6. The ratio of oxides of Taizhuzgen natural zeolite corresponds to the $\mathrm{X}$ type: $\mathrm{SiO}_{2} / \mathrm{Al}_{2} \mathrm{O}_{3}=4.57$ (Table 1 ), and it is an active catalyst for catalytic cracking [18]. Elemental composition of Taizhuzgen zeolite contain $\mathrm{Si}, \mathrm{Al}, \mathrm{K}, \mathrm{Ca}, \mathrm{Fe}, \mathrm{Na}, \mathrm{Mg}, \mathrm{Ti}, \mathrm{Mn}$ whichareactive valence transition metals (Table 2).

SEM images of activated Taizhuzgen zeolite and $2 \% \mathrm{Mo} /$ Taizhuzgen zeolite catalyst are presented in Figures 2 and 3, respectively. The sizes of most particles of activated zeolite were $711.4-1820$ microns. The catalyst based on $2 \% \mathrm{Mo}(\mathrm{VI}) /$ zeolite had uneven surface morphology of small particles - size of most particles ranged from 755.6 to $1800 \mathrm{~nm}$. In general, large-dimensional granular properties are observed for the catalyst particles. Modification of the activated zeolite surface leads to edge alignment and uneven porosity. Consequently, the zeolite particles are enlarged as a result of the modification with molybdenum (VI).

In this research, the effect of the Mo concentration in the catalyst on the yield of products and products of the process of hydrogenation of polymer waste was studied. According to the experimental results (Table 3 ), the highest yield of liquid products $(61.56 \%)$ is achieved using the $2 \% \mathrm{Mo} /$ Taizhuzgen zeolite catalyst. The highest yield of the lightest fraction
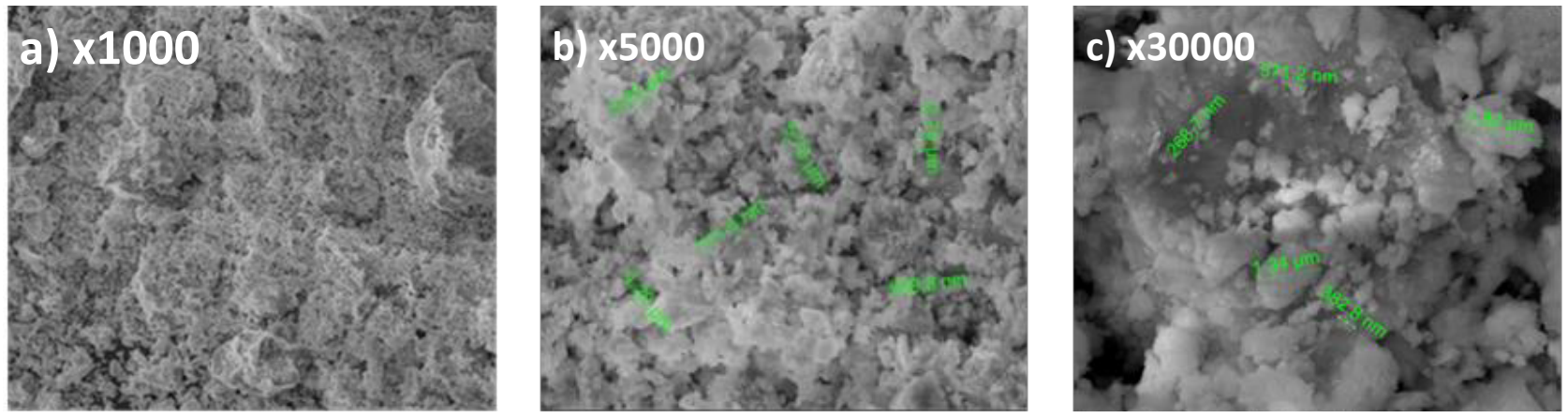

Figure 2 - SEM micrographs of activated Taizhuzgen: a) x1000; b) x5000; c) x30000
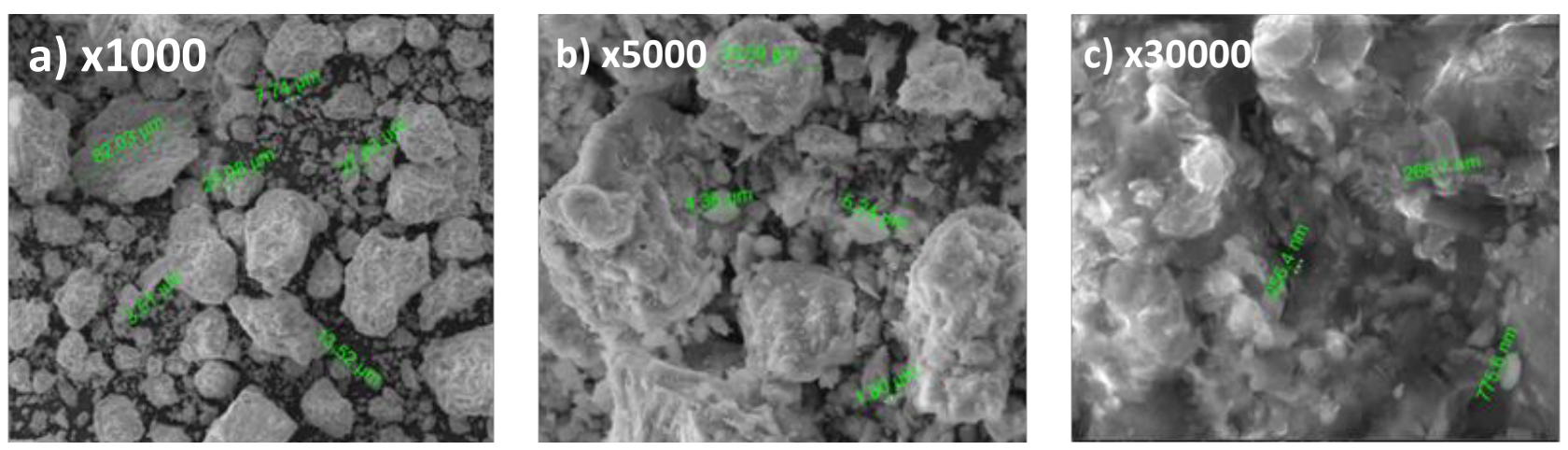

Figure 3 - SEM images of $2 \%$ Mo/Taizhuzgen zeolite catalyst: a) x1000; b) x5000; c) x30000 
$\left(<180^{\circ} \mathrm{C}\right)$ was achieved using the catalyst containing $1 \%$ Mo. Catalyst containing 1.5\% Mo provided the highest yield of the $180-250^{\circ} \mathrm{C}$ fraction $-21.44 \%$. Losses during the experiments were caused by the evaporation of water from the composition of the starting materials, as well as the distillation of synthetic liquid products. Thus, $2 \% \mathrm{Mo} /$ Taizhuzgen zeolite catalyst was used as an optimal catalyst because it provided the highest yield of liquid products.

The group hydrocarbon content of fractions with a boiling point $<180^{\circ} \mathrm{C}, \quad 180-250^{\circ} \mathrm{C}, \quad 250-320^{\circ} \mathrm{C}$ obtained after thermocatalytic hydrogenation treatment of polymer wastes in the presence of $2 \% \mathrm{Mo} /$ Taizhuzgen zeolite catalyst was compared (Figure 4). Highest concentrations of alkanes (54.9\%) and aromatics (27.13\%) were determined in the fraction 250 $320^{\circ} \mathrm{C}$, isoalkanes $(33.5 \%)$ - in the fraction $180-250^{\circ} \mathrm{C}$, alkenes (6.1\%), cycloalkanes $(22.0 \%)$ and cycloalkenes $(5.35 \%)$ - in the fraction $<180^{\circ} \mathrm{C}$.

The material balance was calculated under optimal conditions of in the hydrogenation thermocatalytic processing of polymer residue and Kumkol fuel oil (Table 4).

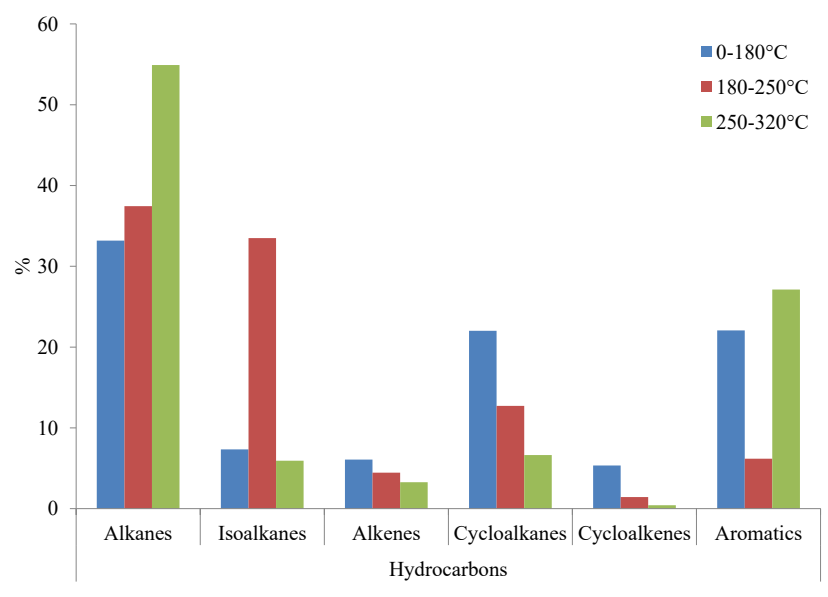

Figure 4 - Composition of distillates obtained using $2 \% \mathrm{Mo} /$ Taizhuzgen zeolite catalyst

Table 3 - Characteristics of products obtained in the process of thermocatalytic hydrogenation of polymer waste

\begin{tabular}{|c|c|c|c|c|c|c|c|c|}
\hline \multirow{2}{*}{ Catalyst } & \multicolumn{4}{|c|}{ Yield of liquid products, mass.\% } & \multirow{2}{*}{$\mathrm{P}_{\max }, \mathrm{MPa}$} & \multirow{2}{*}{$\begin{array}{c}\text { Yield of gas- } \\
\text { es, } \\
\text { mass. } \%\end{array}$} & \multirow{2}{*}{$\begin{array}{c}\text { Yield of solid } \\
\text { waste, } \\
\text { mass.\% }\end{array}$} & \multirow{2}{*}{$\begin{array}{c}\text { Loss, } \\
\text { mass.\% }\end{array}$} \\
\hline & $<180^{\circ} \mathrm{C}$ & $180-250^{\circ} \mathrm{C}$ & $250-320^{\circ} \mathrm{C}$ & $\Sigma_{c}$ & & & & \\
\hline $0.5 \% \mathrm{Mo} /$ Taizhuzgen zeolite & 13.21 & 14.11 & 7.27 & 34.59 & 3.8 & 18.19 & 13.13 & 34.09 \\
\hline 1\% Mo/Taizhuzgen zeolite & 17.52 & 8.79 & 6.58 & 32.89 & 5.9 & 18.19 & 10.91 & 38.01 \\
\hline 1.5\% Mo/Taizhuzgen zeolite & 15.07 & 21.44 & 6.74 & 53.25 & 6.2 & 23.26 & 10.50 & 12.99 \\
\hline 2\% Mo/Taizhuzgen zeolite & 12.44 & 19.12 & 30.00 & 61.56 & 5.1 & 15.31 & 10.80 & 12.33 \\
\hline
\end{tabular}

Table 4 - Material balance of the process with $2 \%$ Mo/Taizhuzgen zeolite

\begin{tabular}{lllllll}
\hline No & Income: & Weight, $\mathrm{g}$ & Mass.\% & Yield: & Weight, $\mathrm{g}$ & Mass.\% \\
\hline 1 & Plasticwastes & 7.00 & 50.0 & Fraction $0-180^{\circ} \mathrm{C}$ & 1.75 & 12.44 \\
2 & Fuel oil & 7.00 & 50.0 & Fraction $180-250^{\circ} \mathrm{C}$ & 2.68 & 19.12 \\
& & & Fraction $250-320^{\circ} \mathrm{C}$ & 4.20 & 30.00 \\
& & & Gas & 2.14 & 15.31 \\
& & & Solid residue & 1.51 & 10.80 \\
& & & Loss & 1.72 & 12.33 \\
\hline & & & & 14.00 & 100 \\
\hline
\end{tabular}

\section{Conclusions}

Thus, among the studied catalysts for the process of thermocatalytic hydrogenation of polymer waste, $61.56 \%$ was a maximum yield of liquid products achieved using a Taizhuzgen zeolite catalyst with Mo concentration $2 \%$. The gasoline fraction obtained using this catalyst mainly consisted of alkanes, aromatics and cycloalkanes, diesel fraction - alkanes, isoalkanes and cycloalkanes, heavy fraction - alkanes and aromatics. It is established that by modifying natural zeolite, Taizhuzgen with Mo salt affects the morphology of the catalyst and, as a result, affects the yield and composition of liquid fractions obtained from polymer waste in different ways.

\section{Conflict of interest}

All authors have read and are familiar with the content of the article and have no conflict of interest. 


\section{References (GOST)}

1 Al-Salem S.M., Antelava A., Constantinou A., Manos G., Dutta A. A review on thermal and catalytic pyrolysis of plastic solid waste(PSW) // Journal of Environmental Management. - 2017. - Vol.197. - P.177-198.

2 Toledo J.M., Aznar M.P., Sancho J.A. Catalytic air gasification of plastic waste(polypropylene) in a fluidized bed, part II: effects of some operating variables onthe quality of the raw gas produced using olivine as the in-bed material // Industrial \& Engineering Chemistry Research. - 2011. - Vol.50. - P.11815-11821.

3 Munir D., Irfan M.F., Usman M.R. Hydrocracking of virgin and waste plastics: A detailed review // Renewable and Sustainable Energy Reviews. - 2018. - Vol.90. - P.490-515.

4 Panda A.K., Singh R.K., Mishra D.K. Thermolysis of waste plastics to liquid fuelA suitable method for plastic waste management and manufacture of value added products - A world prospective // Renewable and Sustainable Energy Reviews. - 2010. - Vol.14. - P.233-248.

5 Sogancioglu M., Ahmetali G., Yel E. A comparative study on waste pyrolysis liquid products quantity and energy recovery potential // Energy Procedia. - 2017. - Vol.118. - P.221-226.

6 Hazrat M.A., Rasul M.G., Khan M.M.K. A syudy on thermo-catalutic degradation for production of clean transport fuel and reducing plastic wastes // Procedia Engineering. - 2015. - Vol.105. - P.865-876.

7 Kaminsky W., Zorriqueta I.J.N., Catalytical and thermal pyrolysis of polyolefins // Journal of Analytical and Applied Pyrolysis. - 2007. - Vol.79(1-2). - P.368-374.

8 Marcilla A., Gomez-Siurana A., Valdes, F. Catalytic pyrolysis of LDPE over H-beta and HZSM-5 zeolites in dynamic conditions Study of the evolution of the process // Journal of Analytical and Applied Pyrolysis. - 2007. - Vol.79(1-2). - P.433-442.

9 Olazar M., Lopez G., Amutio M., Elordi G., Aguado R., Bilbao J. Influence of FCC catalyst steaming on HDPE pyrolysis product distribution // Journal of Analytical and Applied Pyrolysis. - 2009. - Vol.85(1-2). - P.359-365.

10 Shah P., Strezov V., Nelson P.F. X-Ray absorption near edge structure spectrometry study of nickel and lead speciation in coals and coal combustion products // Energy \& Fuels. - 2009. - Vol.23. - P.1518-1525.

11 Paraschiv M., Kuncser R., Tazerout M., Prisecaru T. New energy value chain through pyrolysis of hospital plastic waste // Applied Thermal Engineering. - 2015. - Vol.87. - P.424-433.

12 Williams P.T., Slaney E. Analysis of products from the pyrolysis and liquefaction of single plastics and waste plastic mixtures // Resources Conservation and Recycling. - 2007. - Vol.51(4). - P.754-769.

13 Miandad R., Barakat M.A., Aburiazaiza A.S., Rehan M., Ismail I.M.I., Nizami A.S. Effect of plastic waste types on pyrolysis liquid oil // International Biodeterioration \& Biodegradation. - 2016. - Vol.119. - P.239-252.

14 Zaiku X., Zhicheng L., Yangdong W., Qihua Y., Longya X., Weiping D. An overview of recent development in composite catalysts fromporous materials for various reactions and processes // International Journal of Molecular Sciences. - 2010. - Vol.11(5). P.2152-2187.

15 Luo M., Curtis C.W. Thermal and catalytic coprocessing of Illinois No 6. Coal with model and commingled waste plastics // FuelProcessing Technology. - 1996. - Vol.49(1-3). - P.91-117.

16 Joo H.K., Curtis C.W. Catalytic coprocessing of LDPE with coal and petroleum residusing different catalysts // Fuel Processing Technology. - 1998. - Vol.53. - P.197-214.

17 Aubakirov Y.A., Tashmuhambetova Zh.Kh., Akhmetova F.Zh., Burkhanbekov K.E., Sassykova L.R., Tilla N.M. Hydrogenation catalytic thermal recycling of polymeric wastes in the presence of molybdenum catalysts deposited on natural zeolite // Herald of the KBTU. - 2018. - Vol.15. - P.22-27. (In Kazakh)

18 Aubakirov Y.A., Sassykova L.R., Tashmukhambetova Zh.Kh., Akhmetova F.Zh., Sendilvelan S., et al. Abildin Thermo-catalytic processing of polymer waste over catalysts on the basis of natural zeolite from the Tayzhuzgen field (Kazakhstan) modified by molybdenum // Rasayan Journal of Chemistry. - 2019. - Vol.12. - P.1701-1709.

19 Burkhanbekov K., Aubakirov Y., Tashmukhambetova Z., Abildin T. (2019). Thermal processing of waste tires with heavy oil residue in the presence of Tayzhuzgen zeolite // Journal of Material Cycles and Waste Management. - 2019. - Vol.21. - P.633-641.

\section{References}

1 Al-Salem SM, Antelava A, Constantinou A, Manos G, Dutta A (2017) J Environ Manage 197:177-198. https://doi.org/10.1016/j. jenvman.2017.03.084

2 Toledo JM, Aznar MP, Sancho JA (2011) Ind Eng Chem Res 50:11815-11821. https://doi.org/10.1021/ie200145p

3 Munir D, Irfan MF, Usman MR (2018) Renew Sust Energ Rev 90:490-515. https://doi.org/10.1016/j.rser.2018.03.034

4 Panda AK, Singh RK, Mishra DK (2010) Renew Sust Energ Rev 14:233-248. https://doi.org/10.1016/j.rser.2009.07.005

5 Sogancioglu M, Ahmetali G, Yel E (2017) Enrgy Proced 118:221-226. https://doi.org/10.1016/j.egypro.2017.07.020

6 Hazrat MA, Rasul MG, Khan MMK (2015) Procedia Engineer 105:865-876. https://doi.org/10.1016/j.proeng.2015.05.108 
7 Kaminsky W, Zorriqueta IJN (2007) J Anal Appl Pyrol 79(1-2):368-374. https://doi.org/10.1016/j.jaap.2006.11.005

8 Marcilla A, Gomez-Siurana A, Valdes F (2007) J Anal Appl Pyrol 79(1-2):433-442. https://doi.org/10.1016/j.jaap.2006.09.006

9 Olazar M, Lopez G, Amutio M, Elordi G, Aguado R, Bilbao J (2009) J Anal Appl Pyrol 85(1-2):359-365. https://doi.org/10.1016/j. jaap.2008.10.016

10 Shah P, Strezov V, Nelson PF (2009) Energ Fuel 23:1518-1525. https://doi.org/10.1021/ef800824d

11 Paraschiv M, Kuncser R, Tazerout M, Prisecaru T (2015) Appl Therm Eng 87:424-433. https://doi.org/10.1016/j. applthermaleng.2015.04.070

12 Williams PT, Slaney E (2007) Resources, Conservation \& Recycling 51:754-769. https://doi.org/10.1016/j.resconrec.2006.12.002

13 Miandad R, Barakat MA, Aburiazaiza AS, Rehan M, Ismail IMI, Nizami AS (2016) Int Biodeter Biodegr 119:239-252. https://doi. org/10.1016/j.ibiod.2016.09.017

14 Zaiku X, Zhicheng L, Yangdong W, Qihua Y, Longya X, Weiping D (2010) Int J Mol Sci 11(5):2152-2187. https://doi.org/10.3390/ ijms11052152

15 Luo M, Curtis CW (1996) Fuel Process Technol 49(1-3):91-117. https://doi.org/10.1016/S0378-3820(96)01043-0

16 Joo HK, Curtis CW (1998) Fuel Process Technol 53:197-214. https://doi.org/10.1016/S0378-3820(97)00074-X

17 Aubakirov YA, Tashmukhambetova ZK, Akhmetova FZ, Burkhanbekov KE, Sassykova LR, Tilla NM (2018) Herald of The KazakhBritish Technical University 15:23-27. (In Kazakh)

18 Aubakirov YA, Sassykova LR, TashmukhambetovaZK, Akhmetova FZ, Sendilvelan S, et al (2019) Rasayan Journal of Chemistry 12:1701-1709. https://doi.org/10.31788/RJC.2019.1245435

19 Burkhanbekov K, Aubakirov Y, Tashmukhambetova Z, Abildin T (2019) J Mater Cycles Waste 21:633-641. https://doi. org/10.1007/s10163-018-00825-x 